\section{Australian funding overhaul set into motion}

Australian medical researchers are looking for a share of an unprecedented boost to public research funding as the Australian government responds to the global financial crisis.

Australia's 2009-2010 federal spending on science and innovation will soar $25 \%$ year on year, a commitment welcomed by the Federation of Australians Scientific and Technological Societies, a research industry association, as "exceptional" and "well above expectations."

The 2009-2010 budget allocates an extra AU\$430 million (\$340 million) for health and medical research, AU\$596 million more for cancer research and a $12 \%$ increase in funding for basic research through the National Health and Medical Research Council.

A major reform of tax incentives will offer a $45 \%$ tax credit for research and development $(\mathrm{R} \& \mathrm{D})$ spending by firms with annual revenue of less than AU\$20 million, available as a cash refund for firms not earning taxable revenue.

Larger firms and those undertaking R\&D in Australia for which the intellectual property is held offshore will be eligible for a $40 \%$ tax credit.

Rebecca James, chief executive officer of advocacy group Research Australia, says the changes offer considerable help to small companies who spend on eligible R\&D.

The local pharmaceutical industry, however, says changes to the Pharmaceutical Benefits Scheme, which subsidizes retail medicine prices, will cost the industry AU\$175 million over five years.

Medicines Australia chief executive Ian Chalmers also rejects the move to require the industry to fund the scheme's advisory committee.

"It is fundamentally inappropriate for the industry to pay for government procurement decision making," Chalmers says.

Simon Grose, Canberra, Australia

\section{Lawsuit sparks calls for libel law reform}

Last summer, the British Chiropractic Association filed a libel suit against science journalist Simon Singh for writing that the association "happily promotes bogus treatments." In May, the two parties met for a preliminary hearing. Singh lost the first round, but has since won the support of thousands of scientists, journalists, parliamentarians and others who say that British libel laws are stifling scientific debate.

The brouhaha began in April 2008, when Singh wrote an article for The Guardian's comment page in which he criticized the British Chiropractic Association (BCA) for offering up chiropractic as an effective treatment for childhood maladies such as asthma and colic. The article coincided with both Chiropractic Awareness Week and the release of Singh's book, Trick or Treatment: Alternative Medicine on Trial. "I thought it was quite an interesting, important and well-researched article," Singh said in an online statement, "but, unfortunately, the British Chiropractic Association claimed I had defamed their reputation."

The BCA demanded an apology and a retraction. The Guardian offered to publish a 500 -word response or to print a clarification. When an agreement could not be reached, the BCA decided to sue Singh (rather than the newspaper) as an "act of last resort."

The May hearing was an attempt to ferret out exactly what Singh meant by "bogus." The BCA alleges that Singh implied that the association "deliberately promotes fraudulent chiropractic treatments." Singh, however, claims that he simply meant that the treatments are not evidence based. The judge sided with the BCA, but Singh plans to appeal the ruling.

Singh's case has sparked calls for reform of British libel laws, which place the burden of proof on the defendant rather than on the plaintiff. In June, the British organization Sense About Science published a statement arguing that the laws "have a chilling effect, which deters scientists, journalists and science writers from engaging in important disputes." At press time, the statement had more than 12,000 signatures.

Some suspect that the BCA's lawsuit might actually be backfiring and causing people to criticize it. According to Steven Novella, a Yale neurologist and frequent blogger, "The more you try to push it down, the more it will bubble up."

\section{Cassandra Willyard, New York}

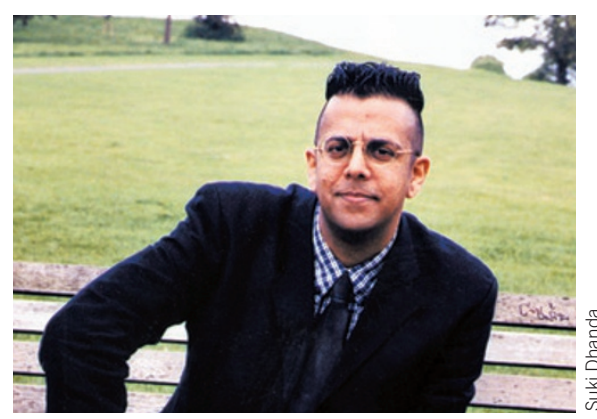

Speaking out: Simon Singh

\section{Indian universities face misconduct allegations}

A report by the Times of India newspaper alleging that admissions to medical school might have been sold for money at two private institutions has stirred controversy in India. The newspaper has said it caught officials on tape demanding as much as Rs 4 million $(\$ 80,000)$ for admission to medical degree programs without providing receipts.

In the wake of these allegations, the country's education ministry has ordered an official probe into the claims. The two institutions, Sri Ramachandra University and Sree Balaji Medical College, affiliated with Bharat University - both in the south Indian state of Tamilnadu-risk derecognition if found guilty, education ministry spokesperson Mamta Verma told Nature Medicine.

Dayanand Dongaonkar, secretary general of the Association of Indian Universities in New Delhi is waiting for the outcome of the probe, saying that "we will decide about what action to take on our members once the government investigation is over."

Ramachandra University's vice chancellor S. Rangaswami did not reply to request for comments. The university has an ongoing research alliance with Harvard University in the US.

"We have been in contact with the leadership of Sri Ramachandra University, with which we have a professional services agreement, and have expressed our wish to see the matter resolved in appropriate fashion," says Chris Railey, director of communications and marketing for Partners Harvard Medical International.

Balaji College, the newspaper found from the college's website, was chaired by S. Jagathrakshakan, a junior minister in the government.

But after the exposé his name reportedly disappeared from the website. Nature Medicine was unable to reach S. Jagathrakshakan for comment.

The admission scam has prompted the education ministry to review the functioning of 123 universities, including 55 medical colleges that obtained the 'deemed status' in last five years.

Killugudi Jayaraman, Bangalore, India 